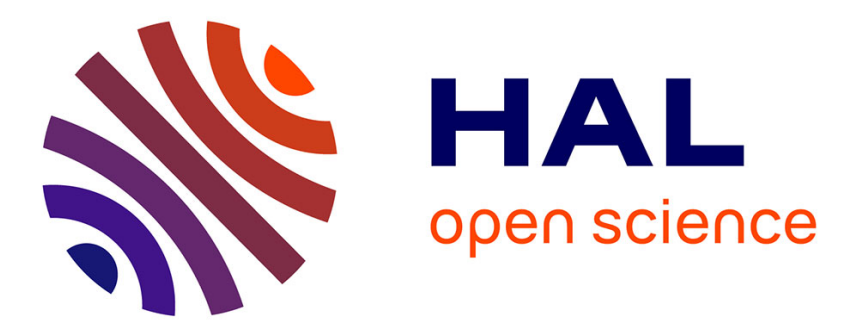

\title{
Stable carbon isotope evidence for the microbial origin of C14-C18 n-alkanoic acids in soils
}

Eric Lichtfouse, Gersende Berthier, Sabine Houot, Enrique Barriuso, Valerie Bergheaud, Tatiana Vallaeys

\section{- To cite this version:}

Eric Lichtfouse, Gersende Berthier, Sabine Houot, Enrique Barriuso, Valerie Bergheaud, et al.. Stable carbon isotope evidence for the microbial origin of C14-C18 n-alkanoic acids in soils. Organic Geochemistry, 1995, 23 (9), pp.849-852. 10.1016/0146-6380(95)80006-D . hal-00192937

\section{HAL Id: hal-00192937 https://hal.science/hal-00192937}

Submitted on 29 Nov 2007

HAL is a multi-disciplinary open access archive for the deposit and dissemination of scientific research documents, whether they are published or not. The documents may come from teaching and research institutions in France or abroad, or from public or private research centers.
L'archive ouverte pluridisciplinaire HAL, est destinée au dépôt et à la diffusion de documents scientifiques de niveau recherche, publiés ou non, émanant des établissements d'enseignement et de recherche français ou étrangers, des laboratoires publics ou privés. 
Revised version

Organic Geochemistry 23, 849-852, 1995.

doi:10.1016/0146-6380(95)80006-D

Correspondence: Dr. Eric Lichtfouse, INRA-CMSE-PME, 17, rue Sully, 21000 Dijon, France

Eric.Lichtfouse@dijon.inra.fr

\title{
Stable carbon isotope evidence for the microbial origin of $\mathrm{C}_{14}-\mathrm{C}_{18}$ n-alkanoic acids in soils
}

\author{
Éric LiChtFouse, ${ }^{1 *}$ Gersende Berthier, ${ }^{1}$ SABINe Houot,${ }^{2}$ EnRIQue Barriuso, ${ }^{2}$ \\ VALÉRIE BERGHEAUD ${ }^{2}$ and TATIANA VALLAEYS ${ }^{3}$ \\ ${ }^{1}$ Biogéochimie Isotopique, Université Pierre et Marie Curie, Case 120, 75252 Paris Cx 05, France, \\ ${ }^{2}$ Institut National de la Recherche Agronomique, Science du Sol, 78850 Thiverval-Grignon, France, \\ ${ }^{3}$ Institut National de la Recherche Agronomique, Microbiologie du Sol, 21034 Dijon Cx, France.
}

Abstract- In order to delineate the origin of soil fatty acids, crop soil samples have been incubated for 21 days in vitro either with unlabelled or ${ }^{13} \mathrm{C}$-labelled glucose. Analyses of $\mathrm{C}_{14}-\mathrm{C}_{32} n$-alkanoic acids from monocarboxylic acid fractions, as methyl esters, by gas chromatography-combustion-isotope ratio monitoring mass spectrometry (GC-C-IRMS) show that $\mathrm{C}_{14}, \mathrm{C}_{16}$ and $\mathrm{C}_{18} n$-alkanoic acids are ${ }^{13} \mathrm{C}$-labelled, thus demonstrating their derivation from soil microorganisms, e.g. fungi or bacteria, growing during the experiment. Higher $n$-alkanoic acids, $\mathrm{C}_{16}-\mathrm{C}_{33} n$-alkanes, and $\mathrm{C}_{22}$ $\mathrm{C}_{30} n$-alkanols have not been significantly labelled, thus suggesting their derivation from other sources, e.g. higher plants. This short-term tracer experiment using stable carbon isotopes represents a novel and fruitful approach to study organic matter transformations in soils and other systems such as sediments.

Key words - carbon-13, soil fatty lipids, $n$-alkanes in soils, $n$-alkanols in soils, $n$-alkanoic acids in soils.

\section{INTRODUCTION}

Free or bound fatty acids widely occur in almost all living organism and also where organic matter is being decomposed, such as soils and sediments (Parker, 1969, Morrisson, 1969, Albrecht and Ourisson, 1971, Douglas et al., 1971, Schnitzer and Neyroud, 1975, Seifert, 1977, Schnitzer and Khan, 1978, Perry et al., 1979, Moucawi et al., 1981, Mackenzie et al., 1983, Gillan and Sandstrom, 1985, Grimalt and SaizJimenez, 1989, Grimalt et al., 1989, Dinel et al., 1990, Amblès et al., 1991, De Leeuw and Largeau, 1993, and refs. therein). The precise biological origin and the chemical processes leading to the accumulation of $n$-fatty acids within degraded organic matter are still speculative because 1) these substances may derive from a wide variety of biological precursors, some of which have undoubtedly not been identified yet, 2) the molecular structure of these substances is poorly informative, and 3) little is known about the degradation processes of organic matter. For instance, soil $n$-alkanoic acids may arise by direct input from plants or soil organisms, or by oxydation of soil aliphatic lipids such as $n$-alkanes, $n$-alkanols and $n$-alkanoic acids.

After the pioneering work by Parker (1961-62) on $\delta^{13} \mathrm{C}$ values of individual fatty acids from algae and marine grass, some reports suggest that such isotopic studies

\footnotetext{
*Author for correspondence. Previous contributions: Tetrahedron Lett. 36, 529 (1995), Org. Geochem. 22, 349 and 1023 (1994).
} 
at the molecular level might bring some information on the origin and fate of fatty acids (Vogler and Hayes, 1980, Lichtfouse and Collister, 1992, Abrajano et al., 1994). In soils and sediments, fatty acids are believed to derive from a wide variety of biological sources, such as plants, animals, algae, microbes and their degradation products (Perry et al., 1979, Gillan and Sandstrom, 1985, Grimalt and Saiz-Jimenez, 1989, Grimalt et al., 1989, Dinel et al., 1990, Zelles et al., 1992, Amblès et al., 1994, and refs. therein). On the other hand, the distribution of fatty acids is currently used to quantitate the microbial biomass and even to subgroup individual bacterial species (Perry et al., 1979, Gillan and Sandstrom, 1985, Zelles et al., 1992, Thompson et al., 1993). However, the applicability of such methods relies highly on the biological origin and transformation processes leading to the accumulation of fatty acids in soils and sediments. Also, in order to evaluate the possible microbial origin of soil fatty acids, versus other biological precursors such as higher plants, we wish to report here a simple short-term tracer experiment with ${ }^{13} \mathrm{C}$-labelled glucose.

\section{EXPERIMENTAL}

Soil samples (120 g dry weight) from a crop field (Grignon, France) were sterilized with $\gamma$ rays, then incubated for 21 days in the dark at $\mathrm{pF} 2$ and $28^{\circ} \mathrm{C}$ with soil water from the same field and either distilled water (blank) or D-glucose "Glu" $\left(\delta^{13} \mathrm{C}=\right.$ $10.60 \%$ ) or D-glucose "13C-Glu" $\left(\delta^{13} \mathrm{C} \sim+500 \%\right)$. Soils were dried, finely ground then extracted with $\mathrm{CHCl}_{3}-\mathrm{MeOH}(3 / 1 \mathrm{v} / \mathrm{v})$. Alkane, alcohol and acid fractions were obtained from the extracts as described elsewhere (Lichtfouse et al., 1994a). The alcohol fraction was acetylated with a large excess of acetic anhydride in pyridine $(1 / 1$, $\mathrm{v} / \mathrm{v}) 1 \mathrm{~h}$. at $50^{\circ} \mathrm{C}$. After the addition of water and $\mathrm{CH}_{2} \mathrm{Cl}_{2}(3 \mathrm{x})$, the organic phases were mixed then washed with water $(3 \mathrm{x})$, dried overnight over $\mathrm{CaCl}_{2}$, concentrated under reduced pressure and fractionated by thin layer chromatography on silica gel eluting with $\mathrm{CH}_{2} \mathrm{Cl}_{2}$ (using cholesterol acetate as reference), to give a mono-acetate fraction $\left(\mathrm{R}_{\mathrm{F}} \sim 0.7\right)$. Acid fractions were treated overnight with an excess of diazomethane in diethyl ether. After concentration (ventilated hood), the residue was fractionated by thin layer chromatography on silica gel eluting with ethyl acetate- $n$-hexane $(5 / 95 \mathrm{v} / \mathrm{v}$; using octacosanoic acid methyl ester as reference), to give a mono-ester fraction $\left(\mathrm{R}_{\mathrm{F}} \sim 0.5\right)$. These derivatization reactions, and subsquent thin layer chromatographic steps, were found to be essential for the required chromatographic resolution needed for gas chromatography-combustion-isotope ratio-mass spectrometry (GC-C-IRMS) analysis (Lichtfouse et al., 1991).

Relative abundances of alkanes, alkanols (as mono-acetates), and alkanoic acids (as monomethyl esters), were measured by gas chromatography. They were found to be similar for the incubation of distilled water (blank) and glucose. Carbon isotope analyses are described elsewhere (Lichtfouse et al., 1994b). Isotopic compositions are summurized in Table 1 and are expressed in per mil. relative to the PDB standard: $\delta^{13} \mathrm{C}$ $=\left[\left({ }^{13} \mathrm{C} /{ }^{12} \mathrm{C}\right.\right.$ sample $\left.\left./{ }^{13} \mathrm{C} /{ }^{12} \mathrm{Cstd}\right)-1\right] \times 10^{3}$, where ${ }^{13} \mathrm{C} /{ }^{12} \mathrm{Cstd}=0.0112372 . \delta^{13} \mathrm{C}$ values of $n$-alkanes, $n$-alkanols and $n$-alkanoic acids from the incubation with distilled water (blank) and from the incubation with unlabelled glucose ("Glu") were found to be similar. $\delta^{13} \mathrm{C}$ values of alcohols and monocarboxylic acids, and their respective errors, have been corrected for the contribution of the added methyl group $(\delta=-79.7 \pm 3.9 \%$ ) and acetyl group $(\delta=-50.1 \pm 1.8 \%$ ), respectively, using pure isotopic standards (palmitic acid, arachidic acid, $n$-hexadecanol, cholesterol, $5 \alpha$-cholestan-3 $\beta$-ol, 
ergosterol). The $\delta^{13} \mathrm{C}$ value of the added acetyl group (-50.1\%o) is significantly different from that of the derivatization reagent, acetic anhydride $(-29.3 \pm 0.1 \%)$. This important ${ }^{13} \mathrm{C}$-depletion, which is due to isotopic fractionation of the reagent, shows that derivatization of both the isotopic standards and the samples must be done under the same conditions (temperature, etc.) and preferably at the same time, to allow a correct calculation to be made of the $\delta^{13} \mathrm{C}$ value of the added carbon (see Rieley, 1994). The GC-C-IRMS analysis of $n$-alkanols and sterols as their trimethylsilyl ether derivatives has been previously reported by Jones et al. (1991).

Table $1 . \delta^{13} \mathrm{C}$ values for soil aliphatic lipids, in \%o versus PDB.

\begin{tabular}{|c|c|c|c|c|c|c|c|c|c|}
\hline \multirow{2}{*}{$\begin{array}{l}\text { Carbon } \\
\text { Number }\end{array}$} & \multicolumn{3}{|c|}{ n-Alkanes } & \multicolumn{3}{|c|}{ n-Alkanols } & \multicolumn{3}{|c|}{ n-Alkanoic acids } \\
\hline & Glu & ${ }^{13} \mathrm{C}-\mathrm{Glu}$ & $\Delta \delta^{*}$ & Glu & ${ }^{13} \mathrm{C}-\mathrm{Glu}$ & $\Delta \delta^{*}$ & Glu & ${ }^{13} \mathrm{C}-\mathrm{Glu}$ & $\Delta \delta^{*}$ \\
\hline 14 & & & & & & & -28.4 & -20.0 & \pm 0.9 \\
\hline 16 & -27.1 & -28.4 & \pm 0.6 & & & & -25.0 & -9.9 & \pm 0.9 \\
\hline 17 & -29.4 & -29.9 & \pm 0.6 & & & & & & \\
\hline 18 & -27.7 & -28.1 & \pm 0.6 & & & & -24.8 & -16.9 & \pm 0.9 \\
\hline 20 & & & & & & & -29.5 & -27.5 & \pm 0.8 \\
\hline 21 & & & & & & & -29.9 & -30.3 & \pm 0.8 \\
\hline 22 & & & & -31.4 & -31.1 & \pm 0.8 & -30.7 & -30.1 & \pm 0.8 \\
\hline 23 & & & & & & & -31.5 & -32.0 & \pm 0.8 \\
\hline 24 & & & & -32.3 & -32.2 & \pm 0.8 & -30.0 & -30.3 & \pm 0.8 \\
\hline 25 & -34.4 & -33.0 & \pm 0.6 & & & & -32.9 & -32.1 & \pm 0.8 \\
\hline 26 & & & & -34.7 & -34.3 & \pm 0.8 & -32.5 & -32.8 & \pm 0.8 \\
\hline 27 & -33.3 & -32.6 & \pm 0.6 & & & & -34.5 & -34.2 & \pm 0.8 \\
\hline 28 & & & & -34.3 & -34.2 & \pm 0.8 & -33.9 & -34.1 & \pm 0.8 \\
\hline 29 & -34.7 & -34.9 & \pm 0.5 & & & & -35.3 & -34.9 & \pm 0.8 \\
\hline 30 & & & & -34.2 & -34.5 & \pm 0.8 & -34.5 & -35.1 & \pm 0.8 \\
\hline 31 & -34.5 & -34.9 & \pm 0.5 & & & & -35.1 & -35.0 & \pm 0.7 \\
\hline 32 & & & & & & & -33.6 & -34.7 & \pm 0.7 \\
\hline 33 & -34.2 & -34.6 & \pm 0.5 & & & & & & \\
\hline
\end{tabular}

\footnotetext{
"Experimental errors. For $n$-alkanols and $n$-alkanoic acids, these errors have been corrected for the contribution of the added carbon, in a similar way as that described by Rieley (1994). Noteworthy, the errors for acids decrease from $\pm 0.9 \%$ to $\pm 0.7 \%$ with increasing $C$ number, highlighting the higher precision that should theorically be gained when the acid carbon number increases.
}

\section{RESULTS AND DISCUSSION}

The distribution of $n$-alkanes, $n$-alkanols and $n$-alkanoic acids from soils incubated 21 days either with distilled water (blank) or glucose are similar, showing the absence of alteration of soil biomarker profiles by the glucose experiments. The substances analysed after the glucose experiments are therefore good representatives of those from the initial soil. The isotopic composition of the $n$-alkanes, $n$-alkanols and 
$n$-alkanoic acids from soils incubated either with glucose, or with ${ }^{13} \mathrm{C}$-labelled glucose, are reported in Table $1 . \mathrm{C}_{14}, \mathrm{C}_{16}$ and $\mathrm{C}_{18} n$-alkanoic acids have incoporated ${ }^{13} \mathrm{C}$-enriched carbon (Figure 1), the highest enrichment being observed for the $\mathrm{C}_{16}$ acid $(+8.4 \%$ ) . A portion of these acids must therefore have been synthesized by soil microorganisms growing during the experiment. This finding is in good agreement with the occurrence of $\mathrm{C}_{14}-\mathrm{C}_{18} n$-fatty acids in various microorganisms (Kolattukudy, 1976). An algal origin can be ruled out in our experiment because the glucose incubations were performed in the dark. Also the most probable biological precursors for $\mathrm{C}_{14}-\mathrm{C}_{18} n$-fatty acids are bacteria, fungi and actinomycetes because these organisms are, with algae, the main soil microorganisms.

\section{Soil fatty acids}

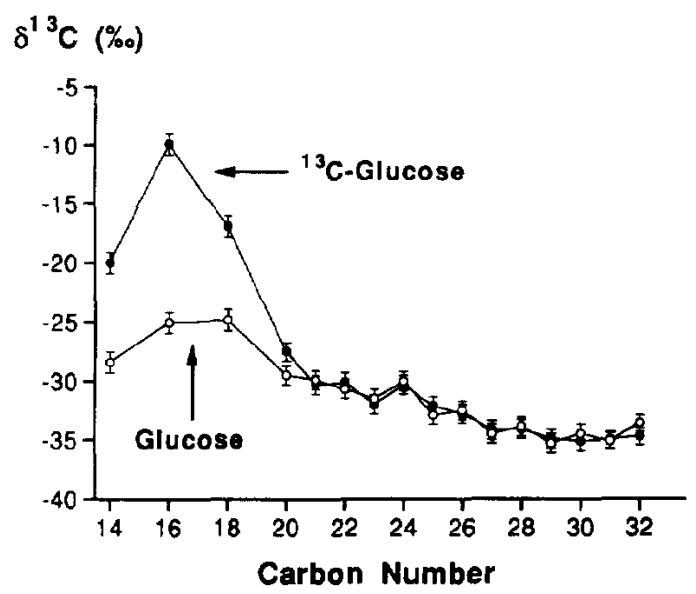

Figure 1. Isotopic composition of $n$-alkanoic acids from soils incubated either with glucose or ${ }^{13} \mathrm{C}$ glucose. Note the ${ }^{13} \mathrm{C}$-enrichment of $\mathrm{C}_{14}, \mathrm{C}_{16}$ and $\mathrm{C}_{18} n$-alkanoic acids.

On the other hand, higher $n$-alkanoic acids, $n$-alkanes and $n$-alkanols have not been significantly labelled during the glucose incubation. Firstly, it is suggested that soil microorganisms are not their biological precursors, at least under the conditions of our experiment. Indeed, these substances are probably derived from organisms which were not grown during the experiment, as suggested by their occurrence, or the occurrence of their immediate precursors, in animals, algae and higher plants (Kolattukudy, 1976).

Secondly, special attention is called to the absence of labelling of the $\mathrm{C}_{16}$ and $\mathrm{C}_{18} n$-alkanes. Indeed, these substances being the close biosynthetic equivalents of $n$ alkanoic acids, it can be inferred that the microorganisms synthesizing the $\mathrm{C}_{16}$ and $\mathrm{C}_{18}$ labelled acids during the glucose experiment did not produce their reduced counterparts in notable amounts. Secondly, the absence of isotopic labelling in the short-chain $n$ alkanes also suggests that their synthesis through abiotic reduction of their acid precursors has not taken place in our experiment, although this might not be true for longer time periods.

In addition, it should be noted that a significant ${ }^{13} \mathrm{C}$-enrichment of short-chain versus long-chain fatty acids occur also in the blank experiment (see the "Glucose" curve on Figure 1). For instance, the $\mathrm{C}_{16}$ and $\mathrm{C}_{18}$ acids show an enrichment of about + 
$10 \%$ relative to the $\mathrm{C}_{31}$ acid. Since the results of the labelled experiment demonstrate a microbial origin for these compounds, this enrichment is apparently associated with their synthesis in the soil. It is therefore suggested that their microbiological precursors are consuming ${ }^{13} \mathrm{C}$-enriched nutrients. The occurrence of carbon sources like sugars and amino acids fits particulary well with this first hypothesis because these nutrients are highly biodegradable, thus preferentially consumed, and are usually ${ }^{13} \mathrm{C}$-enriched relative to the bulk carbon (Deines, 1980). Alternatively, isotope effects associated with assimilation, metabolism and biosynthesis are also possible, as discussed by Hayes (1993). Whatever mechanisms cause the ${ }^{13}$ C-enrichment of short-chain versus longchain acids in the blank sample, the labelled experiment has clearly disclosed that these compounds are of microbial origin.

\section{CONCLUSION}

It has been demonstrated, using isotope tracers, that $\mathrm{C}_{14}, \mathrm{C}_{16}$ and $\mathrm{C}_{18}$ soil $n$-alkanoic acids derive, at least partly, from soil microorganisms. Incubations of soils, or sediments, with ${ }^{13} \mathrm{C}$-labelled substrates, followed by ${ }^{13} \mathrm{C}$ isotope analysis at the molecular level, represent a novel and promising way to study the origin and fate of biological markers.

Acknowledgements- We thank J.-N. Rampon and G. Bardoux for technical assistance. This work was supported by the Institut National de la Recherche Agronomique (Action Intégrée Prioritaire "Écodynamique des substances à caractère polluant").

\section{REFERENCES}

Abrajano JR T. A., Murphy D. E., Fang J., Comet P. and Brooks J. M. (1994)

${ }^{13} \mathrm{C} /{ }^{12} \mathrm{C}$ ratios in individual fatty acids of marine mytilids with and without bacterial symbionts. Org. Geochem. 21, 611-617.

Albrecht P. and Ourisson G. (1971) Biogenic substances in sediments and fossils. Angew. Chem. internat. Edit. 10, 209-225.

Amblès A., Jacquesy J. C., Jambu P., Joffre J. and Maggi-Churin R. (1991) Polar lipid fraction in soil: a kerogen-like matter. Org. Geochem. 17, 341-349.

Amblès A., Parlenti É., Jambu P., Mayoungou P. and Jacquesy J.-C. (1994) n-Alkane oxidation in soil. Formation of internal monoalkenes. Geoderma 64, 111-124.

Deines P. (1980) The isotopic composition of reduced organic carbon. In Handbook of Environmental Isotope Geochemistry (Edited by Fritz P. and Fontes J. Ch.), pp. 329406. Elsevier, Amsterdam.

De Leeuw J.W. and Largeau C. (1993) A review of macromolecular organic compounds that comprise living organisms and their role in kerogen, coal and petroleum formation. In Organic Geochemistry, Principles and Applications (Edited by Engel M. H. and Macko S. A.) pp. 23-72, Plenum Publishing Corp., NewYork.

Dinel H., Schnitzer M. and Mehuys G. R. (1990) Soil lipids: origin, nature, content, decomposition, and effect on soil physical properties. In Soil Biochemistry (Edited by Bollag J.-M. and Stotzky G.), pp. 397-429. Marcel Dekker, New York.

Douglas A. G., Blumer M., Eglinton G. and Douraghi-Zadeh K. (1971) Gaschromatographic-mass spectrometric characterization of naturally-occurring acyclic isoprenoid carboxylic acids. Tetrahedron 27, 1071-1092. 
Gillan F. T. and Sandstrom M. W. (1985) Microbial lipids from a nearshore sediment from Bowling Green Bay, North Queensland: the fatty acid composition of intact

lipid fractions. Org. Geochem. 8, 321-328.

Grimalt J. O., Hermosin B., Yruela I. and Saiz-Jimenez (1989) Lipids of soil humic acids. II. Residual components after hymatomelanic acid extraction. Sci. Total Environ. 81/82, 421-428.

Grimalt J. O. and Saiz-Jimenez C. (1989) Lipids of soil humic acids. I. The hymatomelanic acid fraction. Sci. Total Environ. 81/82, 409-420.

Hayes J. M. (1993) Factors controlling ${ }^{13} \mathrm{C}$ contents of sedimentary organic compounds: principles and evidence. Marine Geol. 113, 111-125.

Jones D. M., Carter J. F., Eglinton G., Jumeau E. J. and Fenwick C. S. (1991)

Determination of $\delta^{13} \mathrm{C}$ values of sedimentary straight chain and cyclic alcohols by

gas chromatography/isotope ratio mass spectrometry. Biol. Mass Spectrom. 20, 641646.

Kolattukudy P. E. (Ed.) (1976) Chemistry and Biochemistry of Natural Waxes. Elsevier, Amsterdam.

Lichtfouse É., Albrecht P., Behar F. and Hayes J. M. (1994a) A molecular and isotopic study of the organic matter from the Paris Basin, France. Geochim. Cosmochim.

Acta 58, 209-221.

Lichtfouse É. and Collister J. W. (1992) Tracing biogenic links of natural organic substances at the molecular level with stable carbon isotopes: $n$-alkanes and $n$ -

alkanoic acids from sediments. Tetrahedron Lett. 33, 8093-8094.

Lichtfouse É., Derenne S., Mariotti A. and Largeau C. (1994b) Possible algal origin of long chain odd $n$-alkanes in immature sediments as revealed by distributions and carbon isotope ratios. Org. Geochem. 22, 1023-1027.

Lichtfouse É., Freeman K. H., Collister J. W. and Merritt D. A. (1991) Enhanced resolution of organic compounds from sediments by isotopic gas chromatographycombustion-mass spectrometry. J. Chromatogr. 585, 177-180.

Mackenzie A. S., Wolff G. A. and Maxwell J. R. (1983) Fatty acids in some biodegraded petroleums. Possible origins and significance. In Advances in Organic Geochemistry 1981 (Edited by Bjorøy et al.), pp. 637-649. Wiley, New York.

Morrisson R. I. (1969) Soil Lipids. In Organic Geochemistry, Methods and Results (Edited by Eglinton G. and Murphy M. T. J.), pp. 558-575. Springer, Berlin.

Moucawi J., Fustec E., Jambu P. and Jacquesy R. (1981) Decomposition of lipids in soils: free and esterified fatty acids, alcohols and ketones. Soil Biol. Biochem. 13, 461-468.

Parker P. L. (1961-62) The isotopic composition of the carbon of fatty acids. Carnegie Inst. Yearbook 61, 187-190.

Parker P. L. (1969) Fatty acids and alcohols. In Organic Geochemistry, Methods and Results (Edited by Eglinton G. and Murphy M. T. J.), pp. 357-373. Springer, Berlin.

Perry G. J., Volkman J. K., Johns R. B. and Bavor Jr H. J. (1979) Fatty acids of microbial origin in contemporary marine sediments. Geochim. Cosmochim. Acta 43, 1715-1725.

Rieley G. (1994) Derivatization of organic compounds prior to gas chromatographiccombustion-isotope ratio mass spectrometric analysis: identification of isotope fractionation processes. Analyst 119, 915-919.

Schnitzer M. and Khan S. U. (Eds.) (1978) Soil Organic Matter. Elsevier, Amsterdam.

Schnitzer M. and Neyroud J. A. (1975) Alkanes and fatty acids in humic substances. Fuel 54, 17-19. 
Seifert W. K. (1977) Carboxylic acids in Petroleum and Sediments. In Progress in the Chemistry of Organic Natural Products, Vol. 32, pp. 1-49. Springer, Berlin.

Thompson I. P., Bailey M. J., Ellis R. J. and Purdy K. J. (1993) Subgrouping of bacterial populations by cellular fatty acid composition. FEMS Microbiol. Ecol. 102, 75-84.

Vogler E. A. and Hayes J. M. (1980) Carbon isotopic composition of carboxyl groups of biosynthesized fatty acids. In Advances in Organic Geochemistry 1979 (Edited by Douglas A. G. and Maxwell J. R.), pp. 697-704. Pergamon, Oxford.

Zelles L., Bai Q. Y., Beck T. and Beese F. (1992) Signature fatty acids in phospholipids and lipopolysaccharides as indicators of microbial biomass and community structure in agricultural soils. Soil Biol. Biochem. 24, 317-323. 